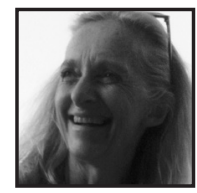

\title{
Trust and Witnessing: Lessons for Dance Education / Professional Development in Community
}

\author{
Miriam Torzillo
}

\begin{abstract}
Dance education is rarely taught in Australian primary schools. A National Arts curriculum was published online in 2014, and ready for implementation the following year. Therefore schools and teachers will be looking for models and frameworks that will help them implement the arts, including dance. The author experienced the work of the community-based dance company Dance Exchange during a summer institute in 2013. For a teacher of dance in a relatively isolated regional town, taking part in the summer institute was a rare opportunity to nourish creative inspiration and a reminder of the importance of the collaborative creative process and the embodied experience within Dance Education.
\end{abstract}

work as a dance specialist teaching creative dance in primary schools in regional Queensland, Australia, a geographical area with few Arts specialists. I also teach the Arts in pre-service teacher education and am a postgraduate student myself. Operating very much in isolation in my area of study means there are limited opportunities to network with colleagues and develop my professional practice. While there are many successful secondary dance programs here, there is very little dance education occurring in primary school education and rarely does it align with the curriculum, which actually foregrounds critical and creative thinking by positioning children and young people as artists (Australian Curriculum, Assessment and Reporting Authority [ACARA], 2013).

Generalist classroom teachers who teach the arts do so often with limited or no knowledge of arts pedagogy. When there are no possibilities for professional 
development within the school (Hardy, 2012; Lowrie, 2014; Mockler, 2013; Thompson \& Harbaugh, 2013), and what is provided by education systems is limited to online digital objects, teachers might have to undertake their own professional development in the community. When teachers elect to challenge the system by choosing their own professional development path, it can become a political act.

Under performative agendas, professional development for teachers in Australia has become a means of satisfying external accountability measures and enforcing systemic priorities (Lingard, 2011), and may be implicit in the narrowing of pedagogic possibilities (Tuinamuana, 2011). As an arts educator, however, it is important to nurture the self, to apply aesthetic values "to one's life, one's existence" (Fornet-Betancourt, Becker, Gomez-Muller, \& Gauthier, 1987, p. 362), and therefore to move beyond accountability to responsibility (Leonard, 2015).

In 2013, I took the opportunity to strengthen my own professional values and skills and to refresh my passion for and commitment to dance, by participating in the Dance Exchange Summer Institute as a student. The experience highlighted for me the relationship between the various roles I play. All of these roles, whether as dance educator, pre-service educator, community artist, dancer, or researcher, support each other. I was keenly aware during the Summer Institute of all these roles, their different impacts on my practice, and the importance of both practice and research to teaching (Beauchamp, Clarke, Hulme, \& Murray, 2015). I have spent many years teaching and learning in Community Arts settings, where I witnessed its transformative effects on adults and children alike, due in large part to its collaborative and inclusive nature (Buys \& Miller, 2009; Selkrig, 2011). This is in line with the commitment of leading Australian and international dance scholars and practitioners to a socially just pedagogy in dance (Garrett \& Meiners, 2014 ). In this paper I explore the experience of the summer institute as an artistic, professional, and research opportunity that would contribute to the design of a pedagogic framework for teaching dance in the primary school.

\section{Professional Development-Arts Education}

A study of the professional development experiences of arts educators led to the design of a matrix as a tool for analyzing and predicting the impact those experiences would have on teacher transformation (Upitis, Smithrim, \& Soren, 1999). The matrix describes the features of professional development experiences at three levels. The third level is suggested as meeting the conditions for profound and long-lasting change. 
The first level is all about feeding the self, becoming part of a community of artists, making art and taking risks, exactly what we ask of our students. The second level comes into play when teachers develop enhanced or changed images of the value of the arts to children and in the curriculum. The third level has an impact on the teacher's personal and professional life, such that major changes are made to their own involvement in the arts and a more pro-active approach taken to consolidating and renewing their teaching practice (Upitis et al., 1999).

The Dance Exchange Summer Institute was not designed for teachers; it did not deal directly with pedagogy, curriculum, and assessment relevant to school teaching. However, it provided a high level of input at the first level: the nurturing of the self. While I have a strong artistic core around which my personal and teaching life is grounded, it is this first level-the nurturing of self, where I am lacking. As well, the summer institute awakened "a feeling of community, encouraged the taking of personal risks and 'the creation of public artifacts'" (p. 27). It was a rich experience because of the way that practical movement work was driven by an aesthetic of inquiry, in which dance is seen as a social and political act that "dissolves binary categories and in its place creates new room for art-making that incorporates 'tolerance, generosity [and] nimbleness'" (Cash, 2011, p. 1). Therefore, the ways of working were in line with a view of dance education that values communal creativity and is based on a "we" paradigm, rather than a competitive skills-based model (Chappell, 2007; Glăveanu, 2014).

\section{Dance Education in the Curriculum}

Current meanings of "dance education" in Australian primary education are diverse. This is because the way dance is taught in primary schools, or whether it is taught at all, varies enormously across and within states and school systems. It is timely to consider the value of dance in education and the meanings it could have within the new Australian National Arts Curriculum (ACARA, 2013). The curriculum makes clear the primacy of the creative process in arts learning, with two key organizing strands, "making and responding" (ACARA, 2013). This is in line with the philosophies and frameworks that first inspired the development of most dance curriculum and syllabi in dance education throughout the world (Laban, 1988). How Dance can and should take its place within Arts education more generally, and in the curriculum as a whole, is the subject of much discussion and debate among dance educators, researchers, and practitioners (Dundas, 2013). When this paper was being written the curriculum materials had gone online, but implantation lagged behind. ACARA has set an "entitlement" that The Arts should be 
taught but not necessarily in every year. In this way, so it is ultimately the responsibility of schools acting within jurisdictional requirements to decide when, how, and what Arts will be taught (Queensland Studies Authority [QSA], 2011).

In Queensland, Australia, generalist classroom teachers of primary school (years 1-6) and music specialists will be called upon to enact this intended curriculum. This may ultimately favour a more inclusive approach to dance education. Whereas an artist in residence model gives precedence to the "gifted and talented" by apprenticing them to a "gifted dancer," the remit of the classroom teacher is to "seek the potential in each person" (Blumenfeld-Jones, 2009, p. 74). The national curriculum makes clear the relationship between making and responding, and the possibility of collaborating with children to co-construct dance.

Making and Responding are intrinsically connected. Together they provide students with knowledge, understanding and skills as artists, performers and audience and develop students' skills in critical and creative thinking. As students make artworks they actively respond to their developing artwork and the artworks of others; as students respond to artworks they draw on the knowledge, understanding and skills acquired through their experiences in making artworks. (ACARA, 2013)

A social constructivist approach is a suitable framework for authentic and productive learning (Vygotsky, 1978). Dance, if taught as intended by the curriculum, positions children as artists and audiences; foregrounding the primacy of making dance (Schiller \& Meiners, 2003). Dance empowers, when it is taught as a creative process, incorporating students' unique ideas and expressions and taking account of their life worlds and experiences (Garrett \& Meiners, 2014). According to state and national quality frameworks, teachers in Queensland are bound to foster inclusive practices in their classrooms (Berlach \& Chambers, 2011). Community dance could therefore provide a source of inspiration for dance education because it is based on '“process-oriented values', including: a focus on participants; collaborative relationships; inclusive practice; opportunities for positive experiences and celebration of diversity" (Amans, 2008, p. 10), It is therefore an accessible and relevant site for professional development of arts educators in the absence of any face-to-face learning offered by systems. For teachers, it is an opportunity to experience the embodied expression of dance and collaborative creativity for themselves and an insight into what the process could be like for the children they teach (Buck, 2005). 


\section{Methodological Approach}

My research charts my personal teaching and learning journey and that of other teachers to further understand the lived curriculum of dance in primary schools and work toward the formulation of a pedagogical framework for teaching it. Case study was used to contain the diverse forms of data, including stories of the researchers' practice and the practice of other teachers; and the engagement and responses of students (Yin, 2014).

This qualitative study was undertaken in regional Queensland Australia. In the first setting during a dance residency taught by the researcher: a research journal was kept; three teachers completed reflective questionnaires and focus group interviews, reflective conversations and mind-mapping conducted with small groups of children from each class. In the other: participant observation of Dance lessons, in three classes taught by a classroom music teacher new to teaching dance was undertaken over two terms; teacher interviews, student reflections, and focus groups were conducted and Dance lessons videoed to produce a thick description of the context. In the third, a class was observed, two teacher interviews conducted and student reflections recorded. Lastly, an auto-ethnographic account of the first author's experiences teaching dance in regional Queensland in urban, rural, and isolated settings, and an ongoing professional conversation with a colleague were included to add detail to this picture of the dance experience of primary school students and teachers.

In this paper, narrative accounts drawn from these diverse settings were selected to assist in a discussion of issues of professional development for teachers in Dance. Furthermore, I wanted to use my own community dance experience to consider how such settings could be of value to generalist teachers seeking to expand their understanding of arts and specifically of dance relevant to the primary school classroom.

The research takes an ontological stance that recognizes the body as an active contributor in thinking and interpreting and values the body's ability to make meaning. In contrast are the impacts on education of technologies that lead to a "repelling of the 'real' or physical world ... producing a distancing ... impacting not only on our spatio-temporal actions 'in-the-world' but also on our emotional 'with-the-world' and 'with-others-in-the-world'"' (Thwaites, 2011, p. 4).

Dance is intrinsically social; it is, therefore, an ideal medium for social and emotional learning (Bresler, 2004; Buck, 2003). Dance, if taught as aesthetic education, offers a 
"distinct and humanizing pedagogy (Bannon \& Sanderson, 2000, p. 10). Viewing this situation through an embodied lens expands the idea of the community of learners (Lave \& Wenger, 1991; Vygotsky, 1978) to include the physical as well as the conceptual and affective aspects. The embodied perspective seeks to bridge the divide between body and mind and emphasizes the interaction between the inner perception of movement and the outward expression (Bresler, 2004).

"Embodiment" entails the union of the mind and body in action or the act of using knowledge produced by the body. Epistemologically, there is a recognition that there are different, integrated ways of knowing and being (Fitzgerald, 2012). According to Liz Lerman, founder of Dance Exchange, because learning is an embodied process, teachers need to utilize the bodies' understanding and awareness in order to teach holistically (Lerman, 2011).

\section{Research Informed by Practice}

Any approach to pedagogy must be based on context, on the real situations of students and teachers. Its credibility will be based on its authenticity. Readers will judge how, or if, it resonates with their situations and experiences. It is not just to literature that one could look for models and frameworks for dance education, but in the real world of the practitioner. In 2013 I had the opportunity to attend a Dance Exchange Summer Institute in Washington, U.S. and to experience firsthand its approach to dance making, which until then I had known only from the company website and YouTube.

The experience led me to think about the possible application of its approach to an Australian primary school setting, and, in particular, its relevance to nonspecialist teachers, primary generalists, and classroom music teachers. In line with the methodology of my post-graduate research, which is grounded in selfstudy, is an approach that regards research as an extension of the researcher's life (Ngunjiri, Hernandez, \& Chang, 2010). I used this experience to enrich my own understanding as I develop a pedagogical framework for teaching dance in primary school classrooms. Schön (1987) used the term "reflective practicum" to describe a process of professional learning that integrates theoretical learning with practice such as found in a design studio, and therefore emphasizing "reflection in action." 


\section{Dancing as Research}

Dance Exchange is an intergenerational company of artists whose mission is "to create dances that arise from asking: Who gets to dance? Where is the dance happening? What is it about? Why does it matter?" (Dance Exchange, 2015a). At the heart of the work of Dance Exchange, or of my experience of their work, were the concepts of trust, witnessing, and a creative process involving both making and responding. Dance Exchange is committed to initiating the creative process in communities and ecosystems? "How and where we live should affect the ways in which we come together to make art" (Meador, 2013). The experience of co-creating dance with children can help to change teachers' foundational understandings of important threshold concepts, including more inclusive definitions of dance and the dancer (Buck \& Rowe, 2015). In dance education, threshold concepts include that everyone can dance; that there is no one truth about dance; and that every dance idea matters (Buck \& Rowe, 2015). When children are allowed to create their own dance, working in self-selected groups they can connect to their life-worlds, experiences, cultural values, and personal tastes, and reflect the group/class identity as a group of dancers collaborating and joining together using shared movement vocabularies, tastes, and styles.

Trust within the Dance Exchange model is based on its methods for drawing ideas and inspiration from people and place: "Each of us has the right to move through our lives, to travel great and small distances with the power of our own bodies" (Meador, 2013). I looked for resonance in my own experience as recorded in my research diary at the end of a dance session with a class of eight year olds (their first creative dance class).

The teacher who had been observing asked, "Can anyone tell me what they learned?" Two students named elements of dance such as time or space and then a student put up her hand and said, "I learned that you don't have to be perfect."

I prized this comment because it highlighted the importance of an inclusive creative process and the need for teachers to trust in that. Arts education should be an opportunity to explore open-ended and complex problems (Eisner, 2002) and to engage in problem finding as well as problem solving (Craft, 2008). When children don't have to "get it right" as they do in much of the rest of the curriculum, "playfulness and invention is enhanced" (Fraser et al., 2007, p. 63). If this were to happen, teachers would need to trust in the children's ideas and be willing to build on them to develop dance in the classroom. This has been borne out by my observations of a classroom where a teacher was attempting dance classes for the first time. The following images and 
researcher's diary document the developing relationship and trust between teacher and students in my first research site.
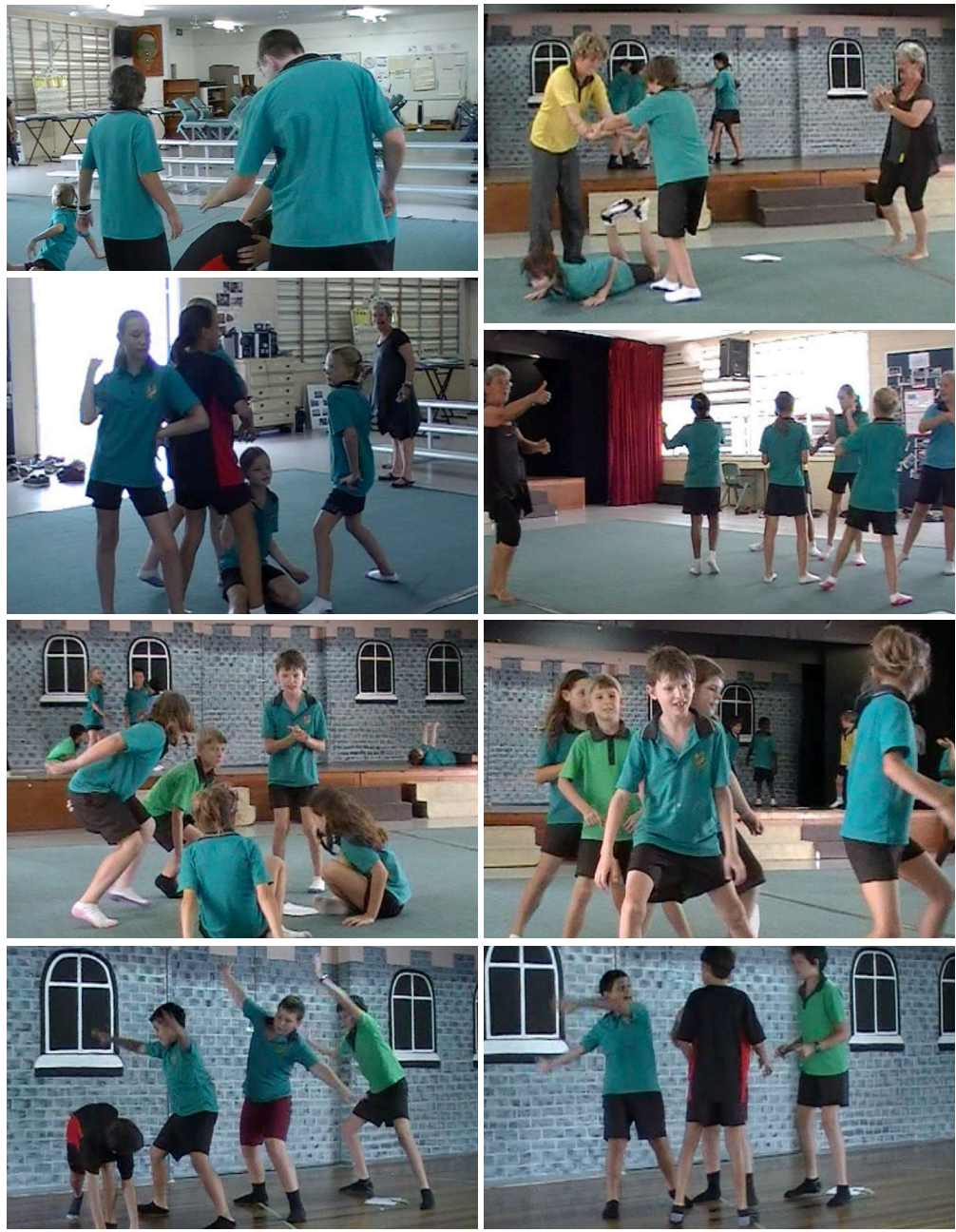

Fig. 1: Students working out the dance problem

Students seem to take seriously the dance problem they had been given to solve and were willing to practice as a group to get it right. Even though they lacked strategies for refining and rehearsing, they stuck at it. The pleasure of achievement was palpable; children showed an interest when the teacher valued what they knew, validated their experience as interesting, and invited questioning. I saw this in one child's obvious pleasure in achievement during the lesson and his response to a positive affirmation of his movement choices. 
"When the emphasis [is] placed upon the pedagogical practice of constructing knowledge, then dialogue and negotiation of meanings and actions became evident" (Buck, 2005, p.30). This emphasis is more relatable for a generalist teacher, as opposed to a skills- or technique-based approach.

Positive interaction between the teacher and students was apparent when she took an interest by watching attentively, praising their concentration or persistence, commenting on their movement choices, and encouraging further development of ideas. This was evident when a student responded to the teacher's encouragement by smiling, turning to his Dance partner and taking him in hand to return enthusiastically to Dance making. This same student had spent the first few lessons with his head bowed and one arm crossed behind his back holding the other arm, hardly making eye contact.

The nature of the dance event described in the anecdotes above, and the teaching and learning that took place, found its structure and some of its meaning from the dance strand within the then Queensland Arts Essential Learnings curriculum (Queensland Studies Authority [QSA], 2011). To some extent, it was constrained by this, as it was by the need to manage behaviour and maintain control. Yet, in comparison to the pedagogy used in generalist classrooms, it was collaborative, provided an element of choice in creating dance, and the freedom to "be" in the body (Stinson, 1997). Students responded to these differences and seemed to adjust to the degree of self-control, persistence, and cooperation it required. My classroom observations documented what was possible, given willingness on the teacher's part to try and to not be afraid of making mistakes, in a non-judgmental space. In addition, there seems to be something in the nature of creative dance that itself is empowering. Bannon and Sanderson (2000) argue that improvisation "encapsulates the essential nature of dance" (p. 18). Despite struggles with behaviour management on the teacher's part and struggles with self-consciousness or uncertainty on the children's, the project resulted in new understandings of the possibilities for dance.

Equipping teachers with an understanding of the verbal language of dance elements, what they mean in practice and some basic choreographic tools, is the key to getting them started in dance education (Ashley, 2005; Buck, 2009; Gross, 2011; Warburton, 2008). "If teachers can see dance as springing from the children's own movement ideas, rather than from preordained steps, then including dance education in their classroom will be more approachable, achievable and inclusive" (Ashley, 2005, p. 10). All teachers have the ability to teach dance, not just dancers or trained dance teachers, if encouraged to develop the confidence to become skilled dance educators 
(Thraves \& Williamson, 1994). A shift in thinking about dance from skills training to a form of bodily research might help to alleviate teachers' fears.

\section{Trust and Witnessing}

On the first day of Dance Exchange Summer Institute, we spent the day at the Anacostia Community Museum, at an exhibition based on the histories and ecologies of the river, and at the Anacostia River itself. This was to be the inspiration for the work that we would make in the following week. Provocations, improvisational tools, and scores were used to develop work that drew from stories and physical places. Many small dances were created, arranged, and performed on site. It was an exhausting but inspiring experience. The combination of museum and river meant that we were drawing on multiple meanings and sensations. The work was site specific. The philosophy and way of working echoed in the axiom, "gathering, moving, making," signifies trust in each individual's creative abilities and process, and trust in the choreographic processes they use as the foundation of their work. Feeling like a dancer again and part of this community was important.

Trust and an open approach to movement exploration are also woven through daily dance practice in classes conducted by the company. Weekly open movement classes for the entire community are based on "the rich possibility of exchanges when people of all ages, backgrounds, abilities, and levels of experience come together in a creative process" (Dance Exchange, 2015b). Mathew Cumbie, one of the dance artists and teachers in the company, encouraged everyone in daily class to "get what you need from the class," describing the movement material taught as a container for individual and group exploration (personal communication, June 2013). Choreographic passes (movement from one side of the room to the other, using a movement rule or score, such as pouring weight into the floor or seeing and falling) were used in daily class as part of each dancer's "research." Further, there was no pressure to "perform" by using recognizable dance vocabulary or focus on technical proficiency.

This reaffirmed my own experience of seeing children absorbed in the process of making dance where there is an open approach to the exploration of a movement image. My journal documents my response to seeing a video of a sharing of dance improvisations by year four students (nine year olds). 
He moves, with sustained, light, controlled energy; the body seeming to know where it should go next and how; the eyes following the hand... The boys in particular were focused on the task at hand. I was struck by their absorption in the movement. I believed I could 'see their thinking' as they moved.

And I was not the only one to have a strong response to the video. The quality of the movement, the concentration of the students, and the apparent transformation of the usually distracted and disruptive students surprised a classroom teacher, who had taught social dance to these same students. Here they were in what seemed to be 'rapt attention to the task', those same students who normally had difficulty attending to the teacher or to learning. She was like me, taken aback by the quality of their movement.

Dance education is said to be an opportunity for "the expansion of our perceptive powers and therefore apprehension of the world that goes beyond surface to expressive and symbolic meanings" (Bannon \& Sanderson, 2000, p. 13). For Dance Exchange, witnessing is important in the gathering of movement ideas, and the process of moving and making of dance. The use of witnessing here is related to the structured form of movement called Authentic Movement involving a mover and a witness, in which the witness provides non-evaluative verbal feedback to the mover; however, in this instance the roles are not so clearly defined because both may be involved in moving and the witness may provide feedback through touch and partnering as well as verbally (Whitehouse, Adler, Chodorow, \& Pallaro, 1999). Witnessing is a key element in Dance Exchange classes, and in dance making where, as a class or in pairs or groups, dancers act as witnesses to another's dance. It is a collaborative act; collaboration that entails responsibility and attention to the other, "allowing oneself to receive messages, to surrender weight into the floor, into your partner, the witnessing, the receiving, the sourcing, the creating and the sharing of ourselves" (Willard, 2013).

In dance education, relationships are central to the experience of children. Collaboration is part of the enjoyment and the value of the process. An exercise in which the whole group moved in the space and then attempted without any cues to pause and then to start moving again in unison, was used as part of warm-up for the performance at the end of the Dance Exchange summer institute. Such an exercise builds awareness and empathy among performers, a valuable skill in a group performance. I have used similar exercises with children to enhance empathy and their interpersonal awareness. Asking children to move together using the same movement image or idea such as "moving as if you are invisible" or imagining the space as something with varied properties that you can play with, encourages children to look at each other and share ideas, rather than a competitive atmosphere when "getting it right" is favoured. I have 
found that asking children what they notice, or think or wonder about each other's dance can elicit more genuine and positive responses than asking them to critique or comment. Modeling the language of appreciation empowers children to give such responses. I did not instruct them in the use of this language explicitly or in a didactic way. Rather, it was a continual part of the conversation, about what we were doing. As I moved around the class, I observed, interacted, and thought aloud, about what I was seeing to help students clarify and develop their own ideas. In one class, children were asked to name moments that stood out for them after viewing each other's short dance sequences. This came at the end of the second lesson in a sequence of four:

This request elicited interesting responses including from one child who noticed the "signature movement when they spiraled their arms and then their whole bodies." This kind of keen observation acts as positive feedback to the other group and reinforces the child's pride in their own developing understanding.

Generalist teachers may be concerned that as they are not dancers themselves they are unable to teach dance (Buck, 2005). The tools and processes of Dance Exchange would be a wonderful starting point for teachers. They resemble in some ways games and activities they may have experienced or used in teaching, in particular, strategies that help teachers structure cooperative learning such as jigsaw, think-pair-share, and expert groups (Bellanca \& Fogarty, 1991). The frames, provocations, and scores are meant to be used and explored in use. It is through use that they could become a part of the repertoire of a teacher (Dance Exchange, 2015c). The Dance Exchange tools are flexible such that teachers would be able to use their own personal practical knowledge of teaching and understanding of their students in order to work with and adapt the tools.

In the tool "equivalents," each word in a text is assigned a corresponding movement. The tool could be used as a whole class activity where all students around the circle offer their equivalent, followed by students in small groups combining selected movement choices to make movement sentences. Alternatively selected movements could be combined as a whole class dance. In my experience, children enjoy the freedom of the many options for interpreting a word, including: literally, as a pun, associatively, sound or shape-based or arbitrary ways and show interest in and an appreciation of the variety of responses from their peers. The repetition of some or all responses could extend students' understanding of the movement elements and the ways in which movements can be extended and elaborated, for example, by repeating a gesture at different levels, or speeds or by exaggerating it. I have used this tool in classrooms when developing dance sequences to interpret poetry. There are no wrong answers in this activity. The explicit nature of the process acts as a scaffold; this gives both 
students and teacher confidence to explore and create, when they aren't expected to model a dance style or teach choreography. The process of copying and repeating all the variations also develops attention, movement memory, and a shared movement vocabulary they can draw on.

In the classroom, the process of dance is mostly a collaborative activity (Bresler, 2004; Buck, 2003). In the social constructivist classroom as envisioned by Vygotsky, the interaction between adult and child is like a dance (Berk \& Winsler, 1995). In the dance classroom, this interaction is stripped back to its essence without the props and ephemera of chairs, tables, whiteboards, or electronic gadgetry, which even for the committed constructivist could be confronting. Yet, where teachers had the opportunity to co-construct dance with their students, they believed creative problem solving, which is an important component of all dance curricula, was the key to its value in the classroom (Buck, 2005).

Research in the U.S. has demonstrated that a hands-off approach to creative dance education can empower students in the middle years to collaboratively create dance to communicate an intended meaning (Giguere, 2011). Teachers in primary schools in Australia, faced with the imperatives of curriculum and reporting, may feel more secure with the support of teaching materials such as the Dance Exchange toolkit, which would help them scaffold teaching and learning, and a framework or model as a basis for including dance education in their classrooms. The Dance Exchange tools are not prescriptive but offer open-ended challenges, a figurative "container" for the ideas they inspire. The choreographic or dance-making tools of Dance Exchange are like the best cake recipe, endlessly adaptable no matter what movement ingredients you use. They can be followed very literally or modified and varied as teachers gain more confidence. They might provide a bridge for the unsure, or the teacher new to dance, to begin co-constructing dance with their students; helping them develop their own movement ideas, rather than teach pre-ordained steps.

The Dance Exchange model is not relevant to a practical skills approach often used in schools because it appears to be less demanding on teachers (Fraser et al., 2007). This may have potential instrumental value, such as keeping students busy, increasing their fitness, producing a performance for the entertainment of parents or the rest of the school, and reinforcing social skills. However, teachers may not have access to the requisite professional development or have the training to deliver dance skills and repertoire. The Dance Exchange model is based on a pedagogy that informs and supports more productive, interesting, and user-friendly ways to engage young children in dance in a classroom setting. "Doing it, making the mistakes, reflecting and 
learning what works for you, is more important than learning more content knowledge" (Buck, 2009, p. 3).

The Dance Exchange model, with its emphasis on trust, witnessing, collaboration, and communication of meaning and a set of tools that are generously offered might be a source of empowerment for teachers. In schools, all children should get to dance, not just those deemed "gifted and talented." Moreover, students should be able to communicate their ideas, feelings and stories through dance that is about something. Dance should occur in schools so that all students can experience it. This is important because all children have bodies and should have the opportunity to learn in and through movement in a collaborative, expressive, and non-competitive environment.

Creative learning needs to be "experienced" through active involvement, and enhanced by collaborative reflective processes (Resnick, 1987; Schön, 1987; Upitis et al., 1999). Teachers need to be involved as learners, so that they can experience the process of art making as their students do. This experience will also help them to appreciate the expressive and creative products of children. "Unlike traditional school-based approaches" and the individualistic and competitive nature of much of the learning taking place in schools, "community arts initiatives may naturally foster social capital by emphasizing the value of collaboration, the respecting and valuing of diversity, extending networks, and prioritizing the sharing of cognitive, emotional, social and physical resources" (Buys \& Miller, 2009, pp. 3-4). Practical professional development, that is based on participatory, inclusive art making such as that of the Dance Exchange Summer Institute, is a reminder that the embodied experience of making dance is what is most important in dance education, for teachers and students alike.

\section{References}

Amans, D. (2008). An introduction to community dance practice. Basingstoke Palgrave: Macmillan.

Ashley, L. (2005). Shape shifting: Choreographic process as research. Dance Rebooted: Initializing the Grid. Retrieved from http:// ausdance.org.au/publications/details/ dance-rebooted-conference-papers
Australian Curriculum, Assessment and Reporting Authority [ACARA]. (2013). Revised Draft Australian Curriculum: The Arts Foundation to Year 10 Sydney. Retrieved from http://www.acara.edu.au/verve/_resources/ Draft_Arts_Curriculum_22_February_2013. pdf. 
Bannon, F., \& Sanderson, P. (2000). Experience every moment: Aesthetically significant dance education. Research in Dance Education, 1(1), 9-26. doi:10.1080/146478900 50006550

Beauchamp, G., Clarke, L., Hulme, M., \& Murray, J. (2015). Teacher education in the United Kingdom post devolution: Convergences and divergences. Oxford Review of Education, 41(2), 154-170. doi:10.1080/03054985.2015.10 17403

Bellanca, J., \& Fogarty, R. (1991). Blueprints for thinking in the cooperative classroom: ERIC.

Berk, L., \& Winsler, A. (1995). Scaffolding children's learning: Vygotsky and early childhood education. Washington, DC: NAEYC.

Berlach, R. G., \& Chambers, D. J. (2011). Interpreting inclusivity: An endeavour of great proportions. International Journal of Inclusive Education, 15(5), 529-539.

Blumenfeld-Jones, D. (2009). Bodily-kinesthetic intelligence and dance education: Critique, revision, and potentials for the democratic ideal. The Journal of Aesthetic Education, 43(1), 59-76.

Bresler, L. (2004). Dancing the Curriculum. In L. Bresler (Ed.), Knowing bodies, moving minds: Towards embodied teaching and learning. Dordrecht: Kluwer.

Buck, R. (2003). The language of dance. Retrieved from http://ausdance.org.au/ ?ACT=73\&file=1326.

Buck, R. (2005). Booting the Tutu: Teachers and Dance in the Classroom. Dance Rebooted: Initializing the Grid. Retrieved from http:// ausdance.org.au/publications/details/ dance-rebooted-conference-papers

Buck, R. (2009). Becoming Aware. Paper presented at the WAAE 2009 World Summit. Newcastle, United Kingdom. http://www. slideshare.net/WAAE/waae-ralph-buck

Buck, R., \& Rowe, N. (2015). Threshold concepts, academic identity and arts curricula design. The Routledge International Handbook of the Arts and Education, 170.

Buys, L., \& Miller, E. (2009). Enhancing social capital in children via school-based community cultural development projects: A pilot study.
International Journal of Education \& the Arts, 10(3), 1-15.

Cash, D. (2011). Participatory Art-Making: Choreographer Liz Lerman's Populist Dance Activism:Unpacking 'Hiking the Horizontal,' Lerman's book on performative dance and community activism. Arts Fuse. Retrieved from http://www.alternet.org/story/150485/ participatory_art-making\%3A_choreogra pher_liz_lerman\%27s_populist_dance_ activism

Chappell, K. (2007). Creativity in primary level dance education: moving beyond assumption. Research in Dance Education, 8(1), 27-52. doi:10.1080/14647890701272795

Craft, A. (2008). Creativity in the School. Retrieved from www.beyond currenthori zons.org. uk/creativity-in-the-school/

Dance Exchange - Mission and vision. (2015a). Retrieved from http://danceexchange.org/ about/mission-vision/

Dance Exchange - Classes. (2015b). Retrieved from http://danceexchange.org/dance-with$\mathrm{dx} /$ classes/

Dance Exchange - Toolbox Home. (2015c). Retrieved from http://danceexchange.org/ toolbox/home.html

Dundas, R. (2013). Dance Education in Australian Schools roundtable. Retrieved from http:// ausdance.org.au/projects/details/2013dance-education-in-australian-schoolsroundtable

Eisner, E. (2002). The arts and the creation of mind. New Haven, CT: Yale University Press.

Fitzgerald, K. (2012). The contribution of embodied ways of knowing in reconceptualising dance in the New Zealand Curriculum: A grounded pathway for the twenty-first century. Retrieved from http://www.tlri. org.nz/sites/default/files/projects/The $\% 20$ Contribution\%20of\%20embodied\%20ways. pdf

Fornet-Betancourt, R., Becker, H., Gomez-Muller, A., \& Gauthier, J. D. (1987). The ethic of care for the self as a practice of freedom: an interview with Michel Foucault on January 20, 1984. Philosophy and Social Criticism, 12(2-3), 112-131. 
Fraser, D., Henderson, C., Price, G., Bevege, F., Gilbert, G., Goodman, A., et al. (2007). The art of the matter: The development and extension of ways of knowing in the arts. Retrieved from www.tlri.org.nz

Garrett, R., \& Meiners, J. (2014). So we can dance! Towards a new inclusive Australian dance curriculum-power, contestations and settlements. International Journal of Education Through Art, 10(2), 221-234.

Giguere, M. (2011). Dancing thoughts: An examination of children, cognition and creative process in dance. Research in Dance Education, 12(1), 5-28. doi:10.1080/14647893. 2011.554975

Glăveanu, V. P. (2014). Distributed creativity: Thinking outside the box of the creative individual: Springer.

Gross, M. J. (2011). Bodies at school: Educating teachers to move (Doctoral dissertation, The Ohio State University). Retrieved from http://rave.ohiolink.edu/etdc/view?acc_ num $=$ osu1313549493

Hardy, I. (2012). The politics of teacher professional development: Policy, research and practice: New York: Routledge.

Laban, R. (1988). Modern educational dance (Vol. 3rd ed). Plymouth: Northcote House.

Lave, J., \& Wenger, E. (1991). Situated learning: Legitimate peripheral participation: Cambridge: Cambridge University Press.

Leonard, S. N. (2015). Stepping outside: collaborative inquiry-based teacher professional learning in a performative policy environment. Professional Development in Education, 41(1), 5-20.

Lerman, L. (2011). Hiking the horizontal: Field notes from a choreographer. Middletown, CT: Wesleyan University Press.

Lingard, B. (2011). Policy as numbers: Ac/counting for educational research. The Australian Educational Researcher, 38(4), 355-382.

Lowrie, T. (2014). An educational practices framework: The potential for empowerment of the teaching profession. Journal of Education for Teaching, 40(1), 34-46.
Meador, C. (2013). Why I Dance, Dance Media. Retrieved from http://dancemagazine.com /issues/June-2010/Why-I-Dance-Cassie -Meador

Mockler, N. (2013). Teacher professional learning in a neoliberal age: Audit, professionalism and identity. Australian Journal of Teacher Education, 38(10), 3.

Ngunjiri, F. W., Hernandez, K.-A. C., \& Chang, H. (2010). Living autoethnography: Connecting life and research. Journal of Research Practice, 6(1), Article E1.

Queensland Studies Authority [QSA]. (2011). Time allocations and entitlement: Implementing the Australian curriculum P-10, Retrieved from http://www.qsa.qld.edu.au/.../early.../ ac_time_alloc_entitlement_report.pdf.

Resnick, L. B. (1987). The 1987 presidential address: Learning in school and out. Educational Researcher, 13-54.

Schiller, W., \& Meiners J. (2003). Dance - moving beyond steps to ideas. In S. Wright (Ed.), Children, meaning-making and the arts. Australia: Pearson Education.

Schön, D. A. (1987). Educating the reflective practitioner: Toward a new design for teaching and learning in the professions. San Francisco: Wiley.

Selkrig, M. (2011). Learning about ourselves from others: Transformation of artists' identities through community-based arts practice. International Journal of Lifelong Education, 30(5), 577-589.

Stinson, S. W. (1997). A question of fun: Adolescent engagement in dance education. Dance Research Journal, 49-69.

Thompson, G., \& Harbaugh, A. G. (2013). A preliminary analysis of teacher perceptions of the effects of NAPLAN on pedagogy and curriculum. The Australian Educational Researcher, 40(3), 299-314.

Thraves, B., \& Williamson, D. (1994). Now for a dance: Integrating dance and movement in primary and early childhood learning. Albert Park, Vic: Phoenix Education. 
Thwaites, T. (2011). Education as spectacle [conference proceedings-refereed paper]. Paper presented at the 41st annual conference of the Philosophy of Education Society of Australasia, Auckland-New Zealand.

Tuinamuana, K. (2011). Teacher professional standards, accountability and ideology: Alternative discourses. Australian Journal of Teacher Education, 36(12), 72-82.

Upitis, R., Smithrim, K., \& Soren, B. J. (1999). When teachers become musicians and artists: Teacher transformation and professional development. Music Education Research, 1(1), 23-36.

Vygotsky, L. S. (1978). Mind in society: The development of higher mental process: Cambridge, MA: Harvard University Press.
Warburton, E. C. (2008). Beyond steps: The need for pedagogical knowledge in dance. Journal of Dance Education, 8(1), 7-12. doi:10. 1080/15290824.2008.10387353

Whitehouse, M. S., Adler, J., Chodorow, J., \& Pallaro, P. (1999). Authentic movement (Vol. 1): London: Jessica Kingsley Publishers.

Willard, S. (2013, June 26). Reflective practice post-Institute (Weblog). Retrieved from http://danceexchange.org/2013/06/26/ reflective-practice-post-institute/

Yin, R. K. (2014). Case study research: Design and methods: Thousand Oaks, California: Sage Publications.

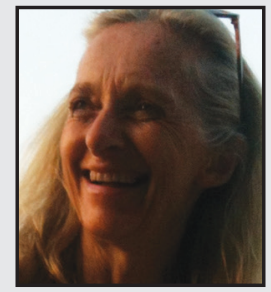

Miriam Torzillo is an independent dance educator and community artist working in regional Queensland Australia, and originally trained in classical and contemporary dance in Sydney and later at the Laban Centre. She is currently pursuing doctoral studies in dance education, working as a dance specialist in primary schools, teaching the arts in pre-service education and continuing to develop her own practice as a choreographer and arts educator in community contexts. 